\title{
DNA points the way ahead in taxonomy
}

\author{
In assessing new approaches, it's time for DNA's unique contribution to take a central role.
}

Sir - The overwhelming task for taxonomy in ecological and biodiversity research arguably requires entirely new approaches. Web-based technology would be a great step towards a more accessible and universal platform, as proposed by $\mathrm{H}$. C. J. Godfray in his Commentary ${ }^{1}$, and backed by F. A. Bisby in Correspondence ${ }^{2}$. But some crucial problems remain, not least the quality and accuracy of submitted information ${ }^{3}$. Many of these problems could be solved if DNA sequences were used as the universal reference standard.

Their usefulness for taxonomic purposes is not disputed. However, all current approaches use DNA as just an additional criterion for identifying a species or a taxon, without attempting to give it a central role. We believe that DNA taxonomy can provide a new scaffold for our accumulated taxonomic knowledge and a reliable tool for species identification and description.

DNA sequences alone are not sufficient to characterize a species ${ }^{4}$, but their unique reproducibility helps to guard against duplicate descriptions ${ }^{3}$. Moreover, collection and curation of extracted DNA samples is technically easy. DNA is very stable and any sample can be split into multiple subsamples, which can be sent to other museums as backups. DNA collections are already needed for the many projects in different laboratories looking at the phylogeny or phylogeography of species. These projects often involve very valuable samples, yet there is no scheme to safeguard them for future reference.

DNA sequencing is often considered to be a complex, expensive technology. But training good taxonomists is also very expensive, and it is a waste of resources to use them only for routine identification of specimens collected in research projects. We need good taxonomists to work on the huge task of matching existing taxonomic information with DNA sequences of new specimens, and to recognize and describe new species. Routine species identification should be the task of specialized DNA sequencing facilities, for which machines are readily available. A DNA facility that could routinely handle about 1,000 samples a day would cost approximately as much as a facility running a transmission and a scanning electron microscope.
We believe that a system based on DNA taxonomy can now be built to integrate the strengths of the traditional system with new technological possibilities, making full use of the invaluable information accumulated over the centuries and giving well-trained taxonomy specialists the opportunity to convert their expertise into broadly reproducible knowledge. We are developing these ideas into a longer article to be published elsewhere soon.

Diethard Tautz ${ }^{\star}$, Peter Arctander $\dagger$, Alessandro Minellił, Richard H. Thomas $\S$, Alfried P. Vogler||

*Institut für Genetik der Universität zu Köln, Weyertal 121, 50931 Köln, Germany $\dagger$ Department of Evolutionary Biology, Institute of Zoology, University of Copenhagen, Universitetsparken 15, DK-2100 Ø Copenhagen, Denmark $\$$ Department of Biology, University of Padova, Via Ugo Bassi 58 B, 35131 Padova, Italy $\$$ Department of Zoology, The Natural History Museum, Cromwell Road, London, SW7 5BD, UK ||Department of Entomology, The Natural History Museum, Cromwell Road, London SW7 5BD, UK

1. Godfray, H. C. J. Nature 417, 17-19 (2002).

2. Bisby, F. A. Nature 418, 367 (2002).

3. Lee, M. S. Y. Nature $417,787-788$ (2002).

4. Ferguson, J. W. H. Biol. J. Linn. Soc. 74, 509-516 (2002)

\section{Israeli concern about Palestinian suffering}

Sir - I am an Israeli chemist and a humanrights volunteer writing in response to your Opinion article "Collaboration in extremis" (Nature 417, 207; 2002), in which you expressed encouragement and support for joint Israeli-Palestinian collaborative science. (See also Correspondence, Nature 417, 689-690; 2002.)

Although well-intentioned, your article is, in my view, off the mark. The situation of the 3.5 million people in Palestine is much worse than you imagine. People are locked in disconnected ghettos, sometimes invaded by the Israeli army. Without a state or citizenship of any country, the Palestinians are unprotected by a legal system, and totally in the power of an army run by people whose notion of 'national security' is to wreak as much destruction in Palestine as they can get away with.

Travel between ghettos is difficult and dangerous, sometimes deadly. External help is hard to get; journalists and humanrights activists are routinely barred by the simple expedient of declaring 'closed military zones'. There is no end in sight, as most Israelis seem unable to grasp that Sharon's policies promote bloodshed on both sides instead of preventing it.
So the laudable suggestions of your article, to promote normalization and collaborations, do not seem relevant. At present, Palestinian academics are unlikely to place high priority on the quality of their scientific collaborations. They are more likely to worry about issues such as being able to get to work tomorrow, being sent to a detention camp, the next military invasion, demolition of their homes, harassment at military roadblocks and, indeed, about survival.

Friends in science, help by wellmeaning foreigners is badly needed here. However, please keep it to the point. Victoria Buch Israel (full address supplied)

\section{Science council replies to neutron claims}

Sir - Last week in Correspondence (Nature 418,367 ; 2002) you published the views of seven subcommittee members of Germany's science council, the Wissenschaftsrat, about the European Spallation Source (ESS).

The council released a statement on nine large-scale facility projects in July this year. These include the ESS, which was evaluated by the subcommittee in a meeting last December. The draft version of their final statement prepared by the Wissenschaftsrat's secretariat was based on the conclusions agreed at that meeting. In April, all subcommittee members were given three weeks to comment on this draft version. With some modifications and additional comments, all except one endorsed the statement on the relevance of the scientific case for the ESS, which some of them are now disputing.

The Wissenschaftsrat considered the overall importance of each of the nine projects in terms of science policy on the basis of each subcommittee's findings. It goes without saying that a science-policy assessment can come to different conclusions from those of a disciplinary evaluation. Funding decisions will be based on the Wissenschaftsrat's comprehensive statement which takes several subcommittees' reports into account.

As chair of the Wissenschaftsrat, I was surprised to read that a statement recently agreed on by all members of a subcommittee except one is now drawn into question by several members. I would find it more helpful if the debate focused on the scientific merit of the ESS project.

Karl Max Einhäupl

Wissenschaftsrat, Brohlerstrasse 11, 50968 Cologne, Germany 